\title{
4
}

\section{Breaking up Mohican Aboriginal Station: 'They got sick of being shunted around'}

When the Central Board Appointed to Watch Over the Interests of Aborigines announced in its annual report in 1861 that Mohican Aboriginal Station would be abandoned, they also foreshadowed, but did not detail, new arrangements that would improve the condition of the natives' and 'reduce the cost of their maintenance'. ${ }^{1}$ It was the responsibility of the new manager, John Green, to find a more amenable location and to achieve the board's ambitious goals: to deliver more and cost less. Taungurung leaders had not consented to the previous removal from their favoured lands at Acheron, but they agreed with this relocation, despite the annoyance of leaving infrastructure and crops. Generational knowledge handed down to Uncle Roy Patterson suggests that:

Soon Aboriginal people were growing food [at Mohican] up on the hill and there was timber that was good for building with [but] the white people shunted them from up there back down near to Cathedral Lane. ${ }^{2}$

\footnotetext{
Victoria, Parliament, First Report of Central Board.

2 Roy Patterson, in conversation with Jennifer Jones, 15 April 2016, DS3001141.
} 
The historical record also notes that Taungurung leaders urged officials to return the settlement to the more productive Acheron site: 'Governor give them the old station and ... black fellow need no more things from him'. ${ }^{3}$ Taungurung leaders wanted to maintain community independence as much as possible. As noted in the previous chapter, many had refused to relocate to Mohican, camping at Narbethong instead, or favouring work and residence on neighbouring stations.

Squatter attitudes towards Aboriginal protection efforts in the district had proven both vexatious and contradictory. Squatters wished to maintain access to a ready workforce, but settler society was scandalised by crossracial relationships enabled by proximity. These attitudes contextualised John Green's new round of negotiations with pastoralists Glass and Nash as he sought a more favourable location for the agricultural activities of the Aboriginal station. Glass and Nash had demonstrated their determination to maintain sole possession of Niagaroon in 1860. Green nevertheless approached the squatters optimistically, 'touching on the portion of land I wanted for the Aborigines'. This plot was adjoining 'the present Aboriginal Station' but within the confines of the run owned by Glass and Nash. Green was pleased (and perhaps surprised) to report that the pastoralists 'have no objections in giving the portion I pointed out to them viz about 200 acres. ${ }^{4}$ Although satisfied with this outcome, Green continued his search for suitable agricultural land. His criteria for an ideal site also included a degree of isolation from white society. Green noted in his letter to Brough Smyth that:

I have found a better portion for farming on the present station about five miles north of the present farm. I therefore think that it would be better not to seek the portion off Glass and Nash's run as the Blacks are more willing to go to this part and they would be better out of the way of everyone. ${ }^{5}$

This new site within Mohican Station appeared to satisfy the requirements of all stakeholders; Taungurung farmers were 'more willing to go to this part' of Mohican Station because it brought them closer to their favoured lands at Acheron; Glass and Nash were not required to relinquish

3 John Green, Acheron Aboriginal Station, 18 October 1861, Mohican Acheron Station JuneDecember 1861, NAA, B312, Item 5, Folio 24.

4 John Green, Acheron Station, to Robert Brough Smyth, 11 January 1862, Acheron Station 1862, NAA, B312, Item 6, Folio 1.

5 John Green, Acheron Station to Robert Brough Smyth, 11 January 1862, Acheron Station 1862, NAA, B312, Item 6, Folio 1. 
200 acres; and, from a Central Board perspective, activities on the plot would decrease cross-racial interactions because it was sufficiently 'out of the way'. Secretary of the Central Board Brough Smyth supported the relocation, indicating his approval by a note in the margins of John Green's report, which read: 'Mr Green would want about $£ 180$ to put the new station in order. Should I ask for an advance?' ${ }^{6}$ Oral history handed down to Uncle Roy also narrates this additional relocation, but takes a different focus. Generational knowledge of the move represents it as yet another instance of Aboriginal adaptation to settler imperatives:

The white people shunted them from up there back down near to Cathedral Lane. They had only been there about a month, and just when the Aboriginal people thought, 'we have got a good place here' they took them down to Narbethong where the old hotel is. ${ }^{7}$

Government records do not detail the duration of Aboriginal settlement on this third farm site before the board's March 1862 decision to 'break up [Mohican] station' altogether. ${ }^{8}$ Oral history suggests, however, that the Taungurung clans were very tired and disheartened by the board's vacillation. As Uncle Roy recounts:

They weren't even asked; they were just told to get out. That's where the Wurundjeri mob come up and grabbed them and took them back to Coranderrk. ${ }^{9}$

The closure of Mohican Station would see the Taungurung clans forced to relinquish their lands and suffer removal to the territories of other groups in the Kulin Nation. The personal investments and priorities of John Green, as I will demonstrate below, had considerable influence on this outcome.

John Green (b. 1830) and his wife Mary (b. 1835) migrated to Australia from Scotland in 1857, and had been living and ministering in the Lilydale and Upper Yarra district for 18 months when Green was appointed an inspector of Aborigines by the Central Board on 9 July 1861. ${ }^{10}$ Diane Barwick suggested that the life experiences and outlook

6 Acheron Station 1862, NAA, B312, Item 6, Folio 1.

7 Roy Patterson, in conversation with Jennifer Jones, 3 March 2016, DS3001137.

8 Minute, 11 March 1862, Board Meeting Minutes 1860-1862, B335/0, Box 1, Folio 76.

9 Roy Patterson, in conversation with Jennifer Jones, 12 July 2016, DS300154-56.

10 Minute, 9 July 1862, Central Board Appointed to Watch Over the Interests of the Aborigines in the Colony of Victoria, NAA, B314, Item 1. 
of the Presbyterian couple fostered their warm connection with the young Wurundjeri families camped at Yering in the Upper Yarra Valley. According to Barwick:

During 1860 [Green] rode over regularly to hold services for the young Wurundjeri couples camped at Yering, who were much the same age as himself and his wife. His wife accompanied him and their babies played together. The Scottish couple shared the puritanical views of their church but they had some sensitivity to the cultural and linguistic differences of minority groups ... [Green's] income was little more than that the Wurundjeri men earned as farm labourers. ${ }^{11}$

Prior to his engagement as an inspector, Green derived financial support from the donations of a small local community of evangelical Presbyterians. He was thus working under 'faith mission' principles that nurtured a degree of fellow feeling between his family and the Wurundjeri at Yering. His strengthening commitment to the Wurundjeri can be gauged by his uptake of their campaign for a reserve of their own selection. Wurundjeri leader Wonga, explained his scheme to form a refuge and school in the Upper Yarra to William Thomas in October 1861. Wonga rejected lands selected by Thomas and the Central Board, and compared this request for land of his own choosing to the successful claim of the Taungurung clans:

Wonga, having seen his friends the Goulburn Tribe comfortably provided for ... said that he had looked out for a spot for the few blacks left in his tribe ... he said, 'Marminarta you very good but black fellow no tell you look out that one country-I want like you get'em Goulburn blacks where black fellows likes'. ${ }^{12}$

John Green apparently accompanied Wonga to this meeting, and thereafter provided faithful support and advocacy for the scheme to procure culturally significant land chosen by Wurundjeri people themselves. Indeed, when William Thomas reflected on the meeting, he observed that 'Revd Mr Green of the Upper Yarra ... had taken much interest in the Aborigines'. ${ }^{13}$ Green and Thomas assisted Wonga to pursue the scheme, which was delayed and then postponed by the board in November 1860 . Board officials still visited land selected by the deputy surveyor-general

11 Barwick, Rebellion at Coranderrk, 55.

12 William Thomas to Redmond Barry, 21 October 1861, quoted in Barwick, Rebellion at Coranderrk,

13 Barwick, Rebellion at Coranderrk, 51. 
in December 1860; however, they did not inspect the site identified by Wurundjeri leaders. Green and Wonga travelled from the Upper Yarra in January 1861 with a deputation protesting this failure. ${ }^{14}$ The Wurundjeri request 'for an aboriginal establishment at Upper Yarra' was again tabled at the meeting of the Central Board on 15 April $1861 .{ }^{15}$ On these occasions, Green demonstrated his capacity for dogged advocacy on behalf of the Wurundjeri clans.

Green's new role as manager of Mohican Station in the Upper Goulburn entailed official obligations towards other clans in the Kulin confederacy, not just the Wurundjeri. Green struggled to balance these dual and perhaps competing commitments. He was openly critical of Mohican Station and pessimistic regarding its prospects. His damning initial assessment, expressed in October 1861 just after the Johnson-Hunter scandal broke, was confirmed in February 1862 and then reiterated when he arrived to take charge of the station on 13 March 1862.

John Green was aware of the ongoing local impact of the relationship between Selina Johnson and Davy Hunter before he took up residence at Mohican Station. Davy Hunter had accompanied John Green on a trip to Melbourne in February 1862, attending an exhibition at the Museum of Illustration with Green and William Thomas. Thomas recorded Green's opinion of the love affair and its local impact in Upper Goulburn society. Thomas clearly had these circumstances in mind when he took close note of Davy Hunter's response to an illustration of Sleeping Beauty, seen at the museum. Thomas noted with apparent amusement that 'Davy is much struck with Sleeping Beauty, he says ["]Marnamuk White Lubra["] (this is the Scamp that got Mr Johnsons Daughter with child)'. ${ }^{16}$ Amateur linguists of the period translated 'marnamuk' as meaning 'that one very good', indicating that the sleeping white woman was visually pleasing. ${ }^{17}$ Thomas offered a sexualised reading of Davy Hunter's encounter with Sleeping Beauty, yet his observation was nevertheless infantalising,

14 Journal entry, 2 January 1861, in Thomas, Journal of William Thomas, 329.

15 Minute, 11 December 1860, Board Meeting Minutes 1860-1862, NAA, B335/0, Box 1, Folio 13; papers submitted for consideration, Central Board for Aborigines, 15 April 1861, Board Meeting Minutes 1860-1862, NAA, B335/0, Box 1, Folio 4.

16 Journal entry, 19 February 1862, in Thomas, Journal of William Thomas, 374.

17 The word 'marnamuk' can be translated as meaning 'that one very good', according to Smyth, The Aborigines of Victoria, 129. 
as a 'scamp' connotes a mischievous but likeable child. William Thomas was notably less benevolent in his recount of Selina Johnson's circumstances. Reflecting upon her commitment to Hunter, Thomas opined:

Strange to say the taste, the Girl persists (by Green's statements) in marrying him when she is 21 Yrs of Age, the father to thwart this has offered even his Station to any white Man that will marry her (from Mr Green). ${ }^{18}$

Given that it was another two years before Henry Johnson managed to find a white man to marry Selina, it can be inferred that Johnson's 'offer' continued to circulate in Upper Goulburn society long after this February 1862 narration. ${ }^{19}$ I suggest that Green's understanding of 'the state' of Mohican Station, recounted below, takes settler attitudes to Taungurung people into account:

Sir I came here on the 13th and have taken everything off Mr Hickson here everything is in very bad order I will bring an account of all to Melbourne next week and I have not had time to write my mind about the state of things here being too busy putting the house in order for my family. PS I hope you will be able to come up with me next week and see the state. ${ }^{20}$

It is probable that John Green's assessment that 'everything is in very bad order' on Mohican Station included the social context, not just the condition of the station plant. Green wrote these words to Brough Smyth five days after making the hard trek up the Black's Spur. He explained that improving the unacceptably low standard of accommodation for his young family had delayed his writing. Here lies another difference between John Green and former manager Robert Hickson. Although they held similar faith-based commitments to their roles in Aboriginal protection, Green was apparently unwilling to accept the same raw living conditions that had satisfied Hickson. 'Faith mission' principles emergent in this era held that mission workers would 'live with adversity, hard work, and loneliness [and] accept sacrifice and suffering. ${ }^{21}$ This meant that an evangelistic agenda took precedence over other duties, which, in the

18 Journal entry, 19 February 1862, in Thomas, Journal of William Thomas, 374.

19 William Fenton, a 'general labourer', married Selina Johnson on 21 June 1864. Reed, 'White Girl', 18.

20 John Green to Robert Brough Smyth, 18 March 1862, Acheron Station 1862, NAA, B312, Item 6, Folio 11.

21 Longworth, 'Upon Past Ebenezers', 178. 
context of Mohican Station, included practical activities oriented towards Aboriginal improvement. Yet Green was so busy 'putting the house in order for my family' that he had not found time to engage with his other duties, including drafting a more detailed complaint about conditions. Green clearly '[identified] with the culture' of the people he served, as endorsed by faith mission principles. ${ }^{22}$ However, his identification seemed to centre on the interests and perspectives of Wurundjeri people.

John Green's responsibilities as an inspector entailed travel to Aboriginal stations around Victoria. Each return to Mohican Station provided fresh opportunity to reassess the liabilities of its location and amenities. Green communicated these disappointments at length in his report of 5 May 1862. It is worth reproducing these grievances in detail, as they provide insight into Green's view of Mohican Aboriginal Station. His report encompasses declining Aboriginal numbers, uncomfortable houses, failed crops, dying stock and wasted money. These woeful circumstances culminate with Green's suggestion that the settlement relocate to the Upper Yarra:

I have the honour to inform you that I have returned to my headquarters (Acheron). I found on my return that a good many of the Blacks have left a few days after I left for Gippsland. Those who have left do not like this place. My Yarra Blacks do not like it either but while I remain here they will also remain. The number of blacks on the station at present are forty-three. Very little work has been done either by me or the blacks when at home have been busy repairing the houses which are in [a] very uncomfortable state. The blacks have been thrashing the wheat, there will only be about twenty bushels of it from fourteen bushels of seed.

One cow and two bullocks have died since I came and the other two bullocks are scarcely able to walk. I believe that it is the cold that is killing the cattle there being plenty of grass. I will be obliged to send my horses to some other place as this is too cold for they are getting poorer everyday without any work. The horses left here when I went to Gippsland are a great deal poorer than those I rode. I can do but little agricultural work until I get more bullocks and a deal of blacksmith work for all the farming implements are out of order. 
My candid opinion is that it would be folly for the Board to spend one sixpence more on this station as I do not think that it will pay the sixpences. But you should come up and see it yourself which would be more satisfactory to you and the Board. And I may state, should the Board give the blacks the portion of land on the Yarra then I believe that the greater part of the Goulburn blacks would settle down with the Yarra blacks as the Yarra blacks have done with them. ${ }^{23}$

According to John Green, a 'portion of land on the Yarra' would alleviate the unhappy circumstances narrated so comprehensively in his letter. Yet, this was not the key point gleaned by readers at the Central Board. They focused instead upon the financial implications of the report, noting 'John Green ... suggests that no more money should be expended by the Board upon the station as he does not consider it will pay expenses' ${ }^{24}$ It is unclear if Green was privy to the board's preferred reading of his report, but he soon amended his approach to maximise benefit from the board's preoccupation with financial performance.

Green's next report, submitted 6 June 1862, emphasised his decision to give Mohican Station a 'fair trial'. This pronouncement, he noted, would require sustained financial output by the board:

The average number of blacks on the station the past month have been forty. Some of the young men work well and I believe will settle and do well if care is taken of them ... It is a great pity that we have not a better Station but I will give it a fair trial, we will see after this year what it is like. If the Board has any money to spare I would ask for $£ 30$ to buy some bullocks for I cannot do anything without them, another of them has died since my last letter. I would also ask for authority to get some blacksmith work done. There have been three deaths since I came here; two of the Yarra tribe and one of the Goulburn, two adults and one child. ${ }^{25}$

Green clearly understood that the board did not 'have any money to spare' when he made this request. William Thomas had recently experienced repeated difficulty gaining promised funds for Mohican Station, including on 9 May 1862, when he had noted in his journal that 'Mr Green's money

23 John Green to Robert Brough Smyth, 5 May 1862, Acheron Station 1862, NAA, B312, Item 6, Folio 24.

24 Acheron Station 1862, NAA, B312, Item 6, Folio 25.

25 John Green to Robert Brough Smyth, 6 June 1862, Acheron Station 1862, NAA, B312, Item 6, Folios 26-26A. 
[was] not in the Treasury' as anticipated. After securing $£ 36$ of the promised amount, Thomas noted on 15 May that he again tried 'to get Green's money fail'. ${ }^{26}$ By focusing upon expenditure and wasted resources at Mohican Station, Green drew attention to the perceived financial precarity of the board's activities. Parliament's chronic underfunding of the Central Board was to become a constant theme of future board reports. For example, their second report, published in 1862, noted that difficulty in arranging supplies for Aboriginal stations and depots 'has been occasioned mainly by the uncertainty of the provision to be made for the blacks by the Parliament'. ${ }^{27}$ John Green finally engaged the attention of the Central Board by claiming that 'a better Station' would not drain the public purse in the same manner as Mohican. This more promising site was on the Upper Yarra, not the Upper Goulburn. The board finally concurred on 21 July 1862, announcing that 'Mr Green [is] to select the new site'. ${ }^{28}$ The Central Board's second report noted that breaking up Acheron/Mohican Station would enable a more informal 'scheme of relief' to be implemented in the Upper Goulburn, one that would be 'free from the costs and embarrassments of a paid protectorate'. ${ }^{29}$ From a government perspective, Mohican had indeed been costly and embarrassing.

\section{'Come join us on our land, at Coranderrk'}

When a piece of land was duly selected in the Upper Yarra Valley 'between Badger's Creek and the Watts River', much delay and uncertainty again beset the project. Objections that had forced the closure of Acheron and Mohican stations were again made-namely, that the site interfered injuriously with the rights of a neighbouring settler'. ${ }^{30}$ The board now feared that 'neighbours' hostility would become a chronic hinderance' to any Aboriginal improvement activities and sought to delay another decision that would be unpopular with settlers. ${ }^{31}$ John Green, however, had already complied with the board's directive to 'remove his station to the Watts River without delay' and his company had departed

26 Journal entry, 9 May and 15 May 1862, in Thomas, Journal of William Thomas, 380-81.

27 Victoria, Parliament, Second Report of the Central Board, 3.

28 Papers submitted for consideration, Central Board for Aborigines, 21 July 1862, Board Meeting Minutes 1860-1862, NAA, B335/0, Box 1, Folio 84.

29 Victoria, Parliament, Second Report of the Central Board, 5.

30 Victoria, Parliament, Third Report of the Central Board, 5-6.

31 Barwick, Rebellion at Coranderrk, 65. 
Mohican Station for Coranderrk. ${ }^{32}$ According to Diane Barwick, the board heard of local objections when 'the Greens and their four children (including a new baby), the Wurundjeri families and the younger Taungurung - 40 in all—were already walking to the new reserve'. ${ }^{33}$ The trekkers arrived in the Upper Yarra in March 1863 and selected a plot adjacent to the contested site. However, uncertainty of tenure continued to disrupt settlement plans until an opportunity arose for a deputation of Wurundjeri, Taungurung and Boonwurrung people to present their case at a public celebration held in honour of the Queen's birthday. On 26 May 1863, Aboriginal representatives presented 'a decorated address that expressed their affection for Queen Victoria' and indicated their right to both 'justice and recognition'. ${ }^{34}$ Not long after, on 30 June 1863, the board achieved the hasty gazettal of Coranderrk, an outcome long attributed to the Kulin's strategic address to the sovereign. ${ }^{35}$ The board justified the gazettal by arguing that the new station was 'well suited to the wants of the blacks, and in such a situation as to give satisfaction to all persons in the neighbourhood'. ${ }^{36}$ Yet, Coranderrk Aboriginal Station was not 'well suited to the wants' of the Taungurung clans.

Generational knowledge handed down to Uncle Roy asserts that Taungurung Elders eventually consented to their peoples' removal to Coranderrk after they had been forced off the new Mohican camp and 'shunted away from Narbethong':

Then Barak said to the people who had a bit of Wurundjeri, 'come join us on our land, at Coranderrk', but the Elders said 'no, we take nothing but our own land'. But when they were shunted away from Narbethong [again] they said, 'we will go down to Coranderrk, we don't want you to move us no more. We will go down to Coranderrk, down to Wurundjeri people on the mission'. ${ }^{37}$

Taungurung oral history emphasises the cumulative impact of broken promises and frequent relocation. By contrast, John Green's account of these negotiations highlighted the young Taungurung men's desire to gain improvement. On 28 July 1863, he observed:

32 Journal entry, 26 January 1863, in Thomas, Journal of William Thomas, 405.

33 Barwick, Rebellion at Coranderrk, 65-66.

34 Nugent, 'Politics of Memory', 104, 107.

35 See van Toorn, Writing Never Arrives Naked.

36 Victoria, Parliament, Third Report of the Central Board, 6.

37 Roy Patterson, in conversation with Jennifer Jones, 3 March 2016, DS3001137. 
So strong was the desire for improvement by this time among the young men belonging to the Goulburn, that they all at once consented to leave, and go to the Yarra. After the young men consented, the old ones consented also. And in the month of Feb'y when I started to proceed to the Yarra all the young men and two old ones started with me, and the others sent their children as a token that they would soon follow. ${ }^{38}$

From the perspective provided by Taungurung generational knowledge, this decision was not marked by a perceived division between young and old; rather, it represented a proud assertion of independence by Taungurung leaders:

So, they walked down on their own without help from Wurundjeri or anybody else. They got sick of being shunted around so they walked down over the Cathedral, down over the Black Spur, and got into Coranderrk. They weren't shifted away from there until they went to Lake Tyers, but my ancestors didn't go; they stayed in Healesville. ${ }^{39}$

Uncle Roy narrates his family history and generational knowledge from a place-based perspective; his object is to demonstrate how Taungurung cultural inheritance was affected by forced removal and by a tenacious effort to maintain connection to Country:

When Daunarung went to Coranderrk, they thought they had done the last shift, it was supposed to be the last shift; but every camp that they went to was supposed to be the last shift! I've done my last shift; I won't be moving off my ancestral Country. ${ }^{40}$

The Black Spur, now the bituminised main road from Narbethong to Healesville, can thus be understood as a 'storied landscape' that carried a disappointed but proud and independent people as they walked into exile at Coranderrk. These Taungurung Elders passed their knowledge and connection to traditional lands down to subsequent generations at Coranderrk, on the border of Taungurung Country. 


\section{'To provide instruction for the children': The changing priorities of the Central Board}

The removal of Taungurung clans to Wurundjeri Country coincided with another significant change made by the Central Board-a change of focus in Aboriginal improvement efforts. Activities at Acheron and Mohican stations emphasised the potential of Aboriginal adults, particularly their adoption of European agriculture. After two years of unsatisfactory progress and expense, the rhetoric of the Central Board shifted to the potential of Aboriginal children. For example, when the Second Report of the Central Board announced the selection of a 'better site, on the north side of the River Yarra', the envisaged activities and achievements highlighted by the board were not agricultural; rather 'it is proposed to found a school for the neglected black and half-caste children, and an asylum for infirm blacks'. ${ }^{41}$ The report, published in 1862, also listed the many perceived vices of Aboriginal adults, before declaring that it was not 'to be expected, that in two years the Board should have produced any marked change in their condition'. Thus, the board justified a shift from protecting Aboriginal adults to shaping Aboriginal children:

Without ceasing to hope for their moral improvement, it is our first duty to supply them with food and shelter; to protect them as far as possible from contact with the debased amongst our own people; and to provide instruction for the children, black and half-caste. ${ }^{42}$

Queries brought to the Central Board in the preceding years had drawn attention to the issue of 'orphaned' Aboriginal children. ${ }^{43}$ In June 1860, the circumstances of a Taungurung 'orphan' prompted the board to seek power to forcibly remove an Aboriginal child from an 'undesirable' situation. The case concerned a Taungurung child referred to as 'the Young Queen of Benalla Tribe'. This girl was in the custody of a publican in Benalla, a white man named James Banfield. A concerned correspondent wrote to the board recommending the removal of the girl, alarmed that she, like others, was being 'kept by pastoralists and publicans for immoral

41 Victoria, Parliament, Second Report of the Central Board, 5.

42 Victoria, Parliament, Second Report of the Central Board, 15.

43 The designation 'orphan', based upon the absence of biological parents in a nuclear family, overlooked wider kinship responsibilities in Aboriginal child raising. 
purposes'. ${ }^{44}$ The publican, who was influential in mining circles, was described in the local paper as 'the respected landlord of the Liverpool Arms'. ${ }^{45}$ Rather than relinquishing the child, James Banfield requested that the board supply 'a grant of land for her maintenance and education'. ${ }^{46}$ When the board met on 30 July 1860 they did not debate the merits of this proposal. They responded instead to a letter from concerned Benalla resident Mrs McKellar who 'earnestly entreated the Board to remove the girl from the house of the Banfields-where she was subject of necessity to the demoralising influences of Hotel life. ${ }^{47}$ The board was uncertain of its power to forcibly take the child from her 'adopted father'. ${ }^{48}$ Advice was promptly sought, as 'the necessity for action was urgent'. Placing the young 'Queen of Benalla' in the Melbourne Orphan Asylum was mooted, but 'a different asylum' was clearly needed 'for native children'. William Thomas, Guardian of Aborigines, was then approached to accept 'charge' of Aboriginal children, and to develop an appropriate scheme. ${ }^{49}$ On 20 August 1860, Crown law officers informed the board that they had 'no power to remove the Young Queen of Benalla' or any other Aboriginal children. ${ }^{50}$ The board sought immediate legislative change to gain 'full power to order as to the custody of minors (Aboriginals and half-castes) in certain cases'. ${ }^{51}$ A letter was sent to Banfield instructing him to 'forward the girl to Melbourne without delay to enable the Board to judge for themselves of her character and education'.52 Banfield refused, and instead recruited a minister of religion Rev. Piper to advocate for their cause, arguing that the Banfields deserved great credit for adopting and educating the girl'. ${ }^{53}$ Banfield must have held some influence, as the board did not pursue this case further.

44 Barwick, Rebellion at Coranderrk, 78.

45 'Snowy River', Ovens and Murray Advertiser, 4 Aug 1860, 2.

46 Minute, 25 June 1860, Central Board Appointed to Watch Over the Interests of the Aborigines in the Colony of Victoria, NAA, B314, Item 1, Roll 1.

47 Minute, 30 July 1860, Central Board Appointed to Watch Over the Interests of the Aborigines in the Colony of Victoria, NAA, B314, Item 1, Roll 1.

48 Minute, 25 June 1860, Board Meeting Minutes 1860-1862, NAA, B335/0, Box 1, Folio 4.; Minute, 30 July 1860, Board Meeting Minutes 1860-1862, NAA, B335/0, Box 1, Folio 51.

49 Minute, 30 July 1860, Central Board Appointed to Watch Over the Interests of the Aborigines in the Colony of Victoria, NAA, B314, Item 1, Roll 1.

50 Minute, 20 August 1860, Central Board Appointed to Watch Over the Interests of the Aborigines in the Colony of Victoria, NAA, B314, Roll 1.

51 Minute, 20 August 1860, Central Board Appointed to Watch Over the Interests of the Aborigines in the Colony of Victoria, NAA, B314, Item 1, Roll 1.

52 Minute, 20 August 1860, Central Board Appointed to Watch Over the Interests of the Aborigines in the Colony of Victoria, NAA, B314, Item 1, Roll 1.

53 Minute, 10 September 1860, Central Board Appointed to Watch Over the Interests of the Aborigines in the Colony of Victoria, NAA, B314, Item 1, Roll 1. 
However, the board persisted in seeking necessary changes to prevent future defiance of their authority over Aboriginal children. Guardian Thomas was empowered to undertake 'the supervision of Aboriginal children, under the charge of a man and a matron in a proposed refuge'. ${ }^{54}$ This role was first performed by the matron at Coranderrk, Mrs Green, in December $1863 .{ }^{55}$ The Central Board noted in its fourth report that, 'as soon as the buildings at Coranderrk were finished' and fit for the occupation of children, it would secure:

Any neglected Aboriginal children amongst the blacks ... who should be maintained and educated by the Board. The letter had reference only to orphans and children who had been abandoned; but it was made known ... that the Central Board would be willing to take charge of any children surrendered to them by the Aborigines themselves. On enquiry it was found that the blacks are reluctant to give up their children. They are, usually, very kind to their offspring, and they are jealous of any interference with them by the whites. ${ }^{56}$

Given his formative encounters with Wurundjeri family groups, John Green was aware that Aboriginal parenting included the active involvement of a circle of kin. Nevertheless, in the coming years Green used his influence to convince Aboriginal parents to relinquish their children. According to Richard Broome:

In all, Green brought sixty children to Coranderrk, many given up by their parents voluntarily as he convinced the parents that 'they were better off with me than exposed to strong temptations'. Many parents followed later. ${ }^{57}$

This rationale for removing Aboriginal children was endorsed throughout the colony by 'honorary correspondents' who were authorised to intervene in Aboriginal affairs. Green explained that:

All the honorary correspondents agree that something ought to be done to rescue the children from growing up in ignorance, and especially the girls, to keep them from a life of infamy. ${ }^{58}$

54 Victoria, Parliament, Fourth Report of the Central Board, 10.

55 Minute, 20 August 1860, Board Meeting Minutes 1860-1862, NAA, B335/0, Box 1, Folio 27;

Victoria, Parliament, Fourth Report of the Central Board, 10.

56 Victoria, Parliament, Fourth Report of the Central Board, 10.

57 Broome, Aboriginal Victorians, 132.

58 Victoria, Parliament, Sixth Report of the Central Board, 12. 
Richard Broome has suggested that, as general inspector of Aborigines, John Green 'was the most active in gaining new residents for the reserve', bringing Aboriginal people 'from the Goulburn, Jim Crow (Mount Franklin), Sandhurst (Bendigo), the Terricks, the Murray and Echuca'. ${ }^{59}$ The 1869 Aborigines Act reformed the Central Board Appointed to Watch Over the Interests of Aborigines, which had been operating in Victoria since 1860, and created a new Central Board for the Protection of Aborigines. These changes finally granted administrators power to forcibly resettle Aboriginal children by order of council. ${ }^{60}$ New child residents secured by these administrative changes included Uncle Roy's grandparents. Their experience of childhood at Coranderrk would be increasingly marked by board intervention and Aboriginal 'rebellion at Coranderrk'. ${ }^{61}$

61 See Barwick, Rebellion at Coranderrk; Nanni and James, Coranderrk. 
This text is taken from On Taungurung Land: Sharing History and Culture, by Uncle Roy Henry Patterson and Jennifer Jones, published 2020 by ANU Press, The Australian National University, Canberra, Australia.

doi.org/10.22459/OTL.2020.04 